\title{
PERANCANGAN DAN PEMBUATAN MODEL SISTEM KENDALI UNTUK PENGENDALIAN DAN PENGAMANAN PINTU GUDANG BERBASIS MIKROKONTROLER AT89S51 DENGAN MENGGUNAKAN MEDIA KARTU IDENTIFIKASI DAN HANDPHONE
}

\author{
Jaenal Arifin $^{1}$, Eka Wahyudi ${ }^{2}$, Eko Agus Riyanto ${ }^{3}$ \\ ${ }^{1,2,3}$ Akademi Teknik Telekomunikasi Sandhy Putra Purwokerto \\ ${ }^{1}$ Jaetoga@yahoo.com
}

\begin{abstract}
ABSTRAK
Pada era globalisasi ini kemajuan di segala aspek kehidupan terus berkembang, seiring dengan perkembangan teknologi. Perkembangan teknologi yang begitu pesat tersebut menjadikan sesuatu lebih mudah dan cepat. Hal ini terlihat dengan ditemukannya peralatanperalatan yang canggih dengan menerapkan prinsip kerja yang serba flexible. Pada teknologi seluler juga telah mengalami perkembangan dimana awalnya hanya digunakan untuk voice call dan SMS (Short Messege Service), kini beberapa perkembangan teknologi seluler sudah bisa digunakan untuk melakukan panggilan video (Video Call), internet, yang lebih utama yaitu dapat mengirimkan DTMF (Dual Tone Multy Frequency). Dengan adanya perkembangan teknologi DTMF ini maka antara teknologi seluler dengan teknologi mikrokontroler AT89S51 dapat diaplikasikan sebagai rangkaian pengendali jarak jauh untuk membuat suatu sistem pengendalian pintu gudang. Serta digunakan sistem kendali kartu sebagai kendali pintu yang utama.
\end{abstract}

Kata kunci : DTMF MT88700, Buffer (IC 74244), Driver Motor, Mikrokontroler AT89S51,

Sensor infra red (IR)

\section{PENDAHULUAN}

Sebelum berkembangnya teknologi semua gudang dikendalikan secara manual baik untuk membuka atau menutup pintu gudang serta sistem pengamanan yang secara manual ternyata kurang efektif dan efisien sehingga sering terjadi kehilangan barang yang disimpan dalam gudang, hal ini disebabkan karena faktor kelalaian manusia dan tingkat pengamanan gudang masih rendah karena menggunakan kunci pengaman yang mudah untuk di bobol. Disini terjadi perbedaan ketika mengunakan sebuah teknologi dimana sistem pengamananya lebih terjaga dan tingkat pengendalianya (membuka dan menutup pintu) menjadi lebih mudah untuk dilakukan. Cara kerja dari sistem digital ini ialah menggunakan media kartu identifikasi dan handphone untuk mengendalikan pintu dan juga untuk pengontrolannya menjadi lebih mudah dan lebih efisien, untuk sistem pengamanya digunakan beberapa sensor untuk menghindari pembobolan gudang ketika pintu gudang dibuka secara paksa, dengan memanfaatkan teknologi maka tingkat keamanan dan pengendalianya lebih mudah dan lebih efisien.

\section{METODOLOGI PENELITIAN}

Metodologi yang digunakan dalam penulisan ini adalah:

\subsection{Studi Literature}

Pada proses penyelesaian Tugas Akhir ini, penulis melakukan pengumpulan referensi pendukung berupa jurnal ilmiah dan buku pustaka.

2.2 Metode pengumpulan data

2.2.1 Data Primer

Diperoleh dari hasil tanya jawab dengan para pihak - pihak yang memiliki pengetahuan tentang elektronika dan mikrokontroler

2.2.2 Data Sekunder

Data diperoleh dari buku - buku yang memiliki pengetahuan tentang elektronika dan mikrokontroler. 


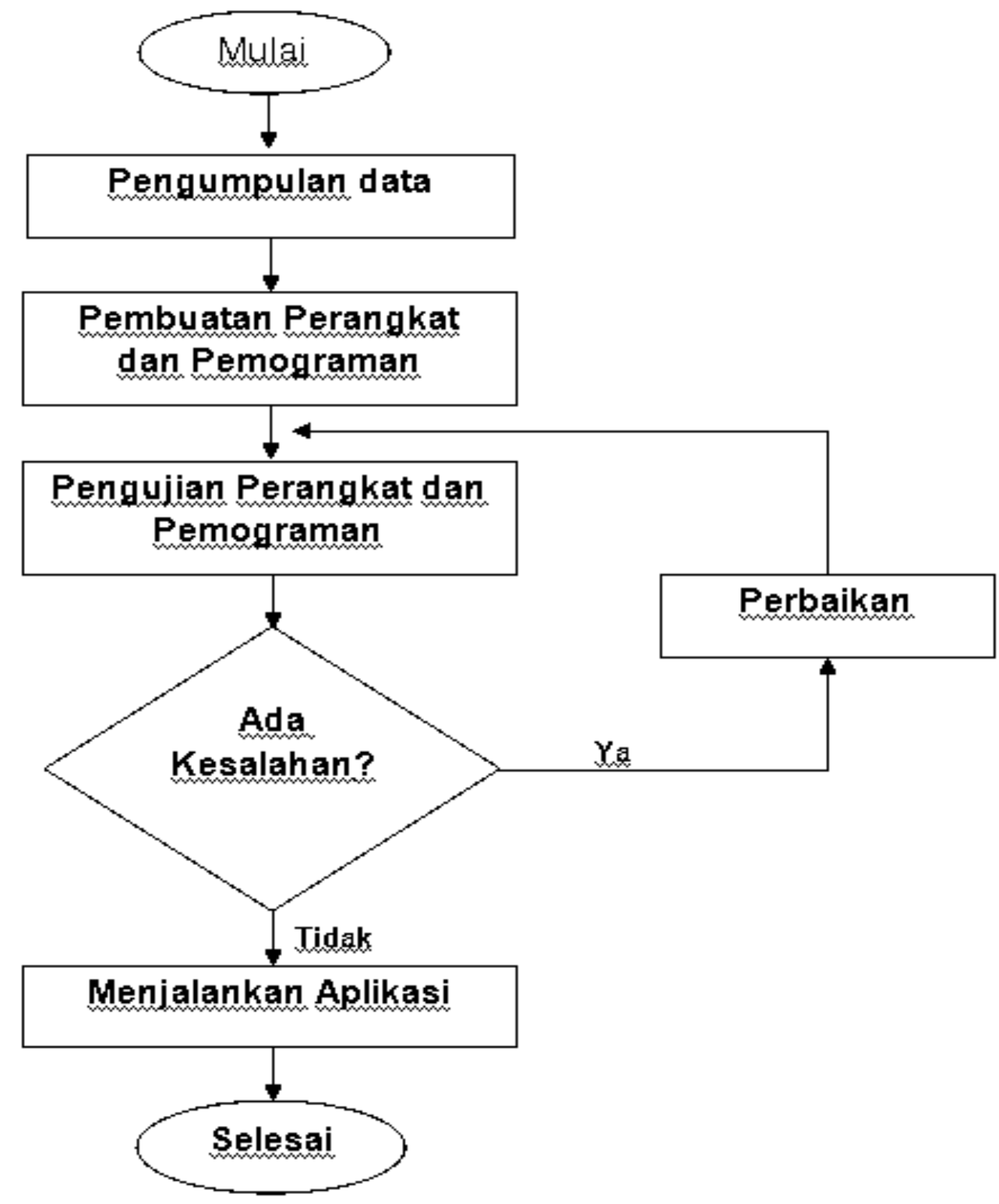

Gambar 1. Flow Chart Perancangan Pembuatan Alat

\section{$2.3 \quad$ Eksperimental}

Metode ini bertujuan untuk mendapatkan rancangan alat yang akan dibuat dengan cara mencari, memodifikasi dan menguji rangkaian-rangkaian elektronika untuk tugas akhir yang digambarkan dalam flow chart gambar 1.

\section{PERANCANGAN PEMBUATAN ALAT}

DAN

Pada pembuatan pintu gerbang via handphone dan kartu teridentifikasi, pintu gerbang dapat bergerak dengan menggunakkan driver motor yang dikontrol menggunakkan mikrokontroller AT89S51. pintu gerbang ini dilengkapi dengan pengendali yang menggunakan sebuah handphone dan kartu teridentifikasi, di mana sifat handphone yang mobile sehingga memudahkan pengguna dalam melakukan pekerjaan membuka pintu dan menutup pintu gerbang, tetapi penggunaan handphone sebagai media kendali ini hanya digunakan untuk 


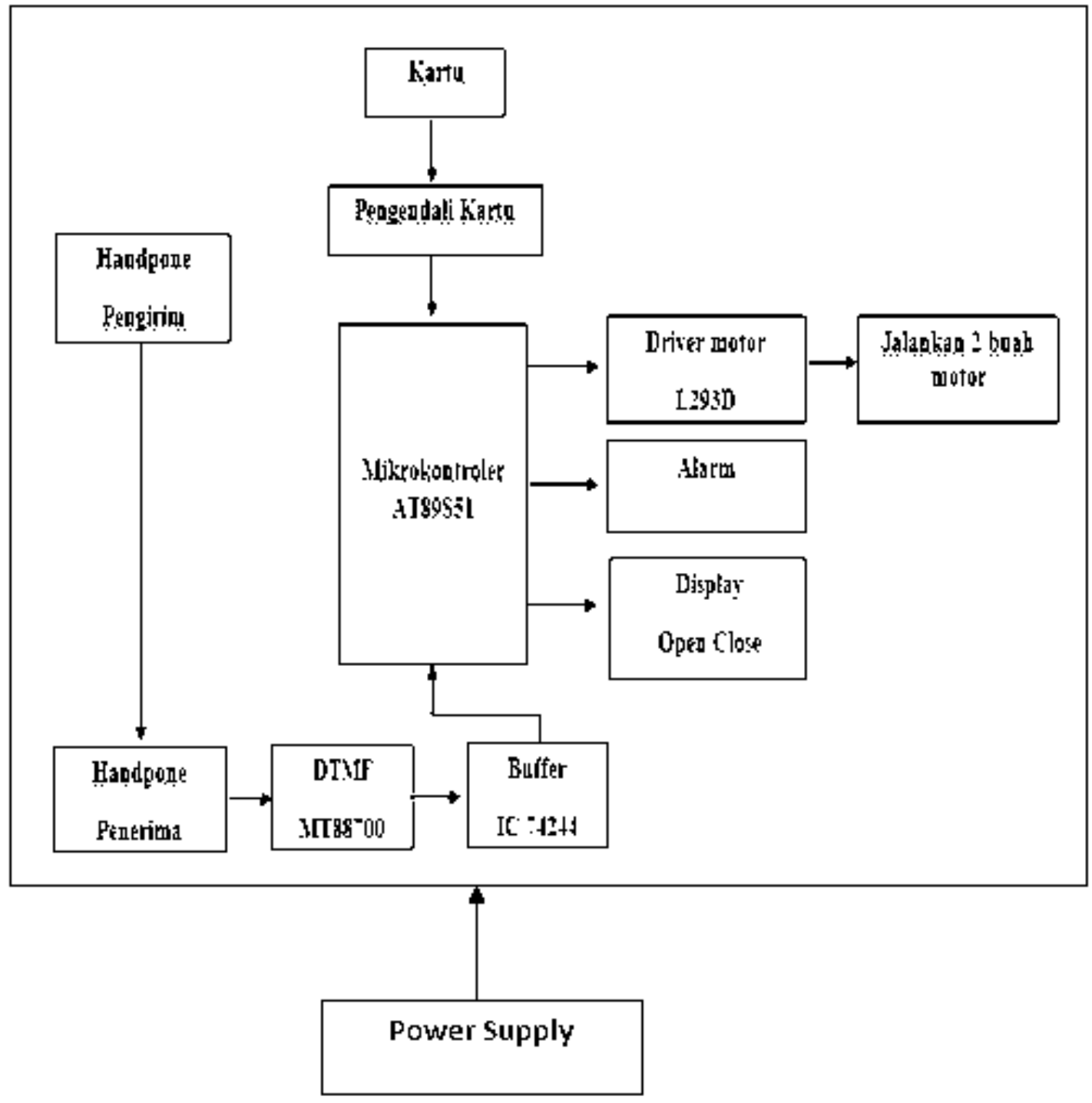

Gambar 2 Rancangan sistem

Power suplay berfungsi untuk memberikan

cadangan karena media kendali utamanya menggunakan media kartu teridentifikasi.

Secara umum konfigurasi dari pintu gerbang terdiri dari input, controller, output. Pada bagian input terdapat sebuah handphone dan kartu teridentifikasi, ini digunakkan untuk menggerakkan pintu gerbang. Pada bagian controller menggunakkan AT89S51. Di sisi output terdapat driver motor dan Motor DC. Rancangan sistem pintu gerbang dapat dilihat pada gambar 2 .

\section{ANALISA DAN PEMBAHASAN}

4. 1 Pengujian Power Suplay suplay tegangan, khususnya ke IC mikrokontroler AT89S51, catu daya yang di gunakan adalah 5 Volt DC. Untuk menurunkan tegangan trafo dari $12 \mathrm{~V}$ menjadi $5 \mathrm{~V}$ maka di gunakan IC voltage regulator LM7805. Pada rangkaian catu daya, dioda 1N4001 berfungsi sebagai penyearah gelombang penuh dari AC ke DC dengan arus sebesar 1 Ampere, sedangkan kapasitor $100 \mu \mathrm{F}$ dan $100 \mathrm{nF}$ berfungsi sebagai filter tegangan $\mathrm{dc}$ atau penghalus pulsa pulsa tegangan yang dihasilkan oleh dioda penyearah. Skema rangkaian catu daya di perlihatkan pada Gambar 3. 


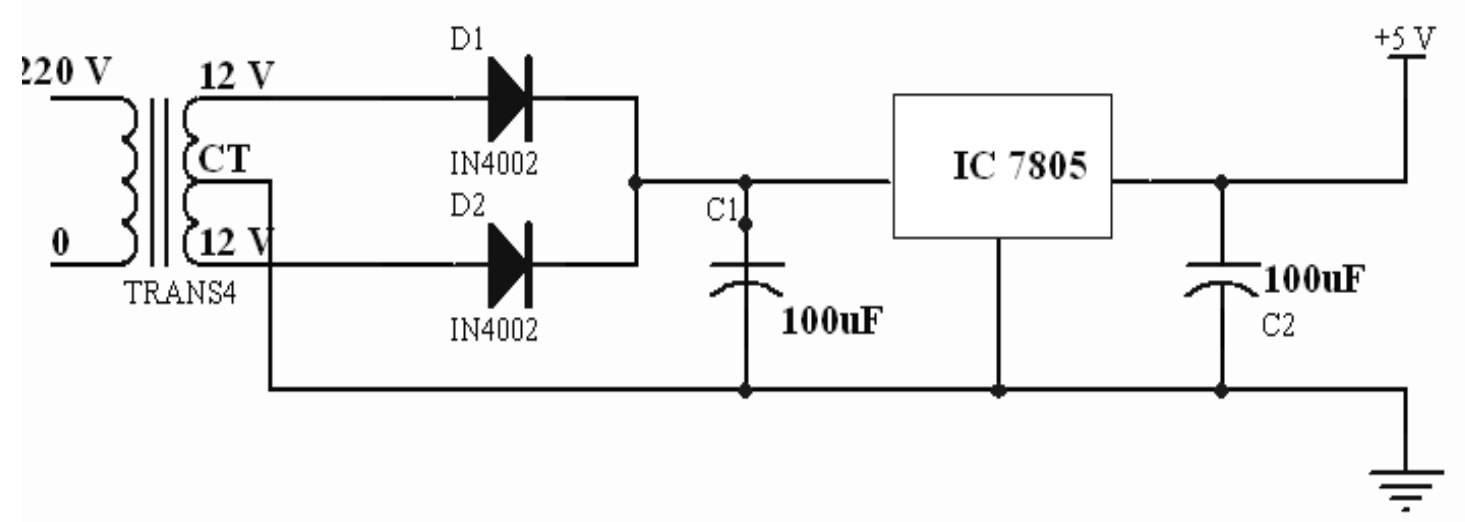

Gambar 3. Skema rangkaian Power Suplay

Dari catu daya 220 Volt melewati Trafo stepdown menjadi 12 Volt kemudian masuk ke jembatan bridge yang berfungsi untuk merubah dari tegangan AC menjadi tegangan DC. Lalu di filter oleh capasitor $100 \mathrm{uF}$, kemudian masuk ke IC LM7805 yang berfungsi sebagai penyetabil tegangan agar tegangan 12 Volt menjadi 5 Volt.
Tabel 1. Hasil Pengujian Power Suplay

\begin{tabular}{|c|c|c|c|c|}
\hline No & Nilai & Teori & $\begin{array}{c}\text { Hasil } \\
\text { Pengukuran }\end{array}$ & Error \\
\hline 1 & VCC & $5 \mathrm{~V}$ & $4.98 \mathrm{~V}$ & $0.02 \mathrm{~V}$ \\
\hline
\end{tabular}

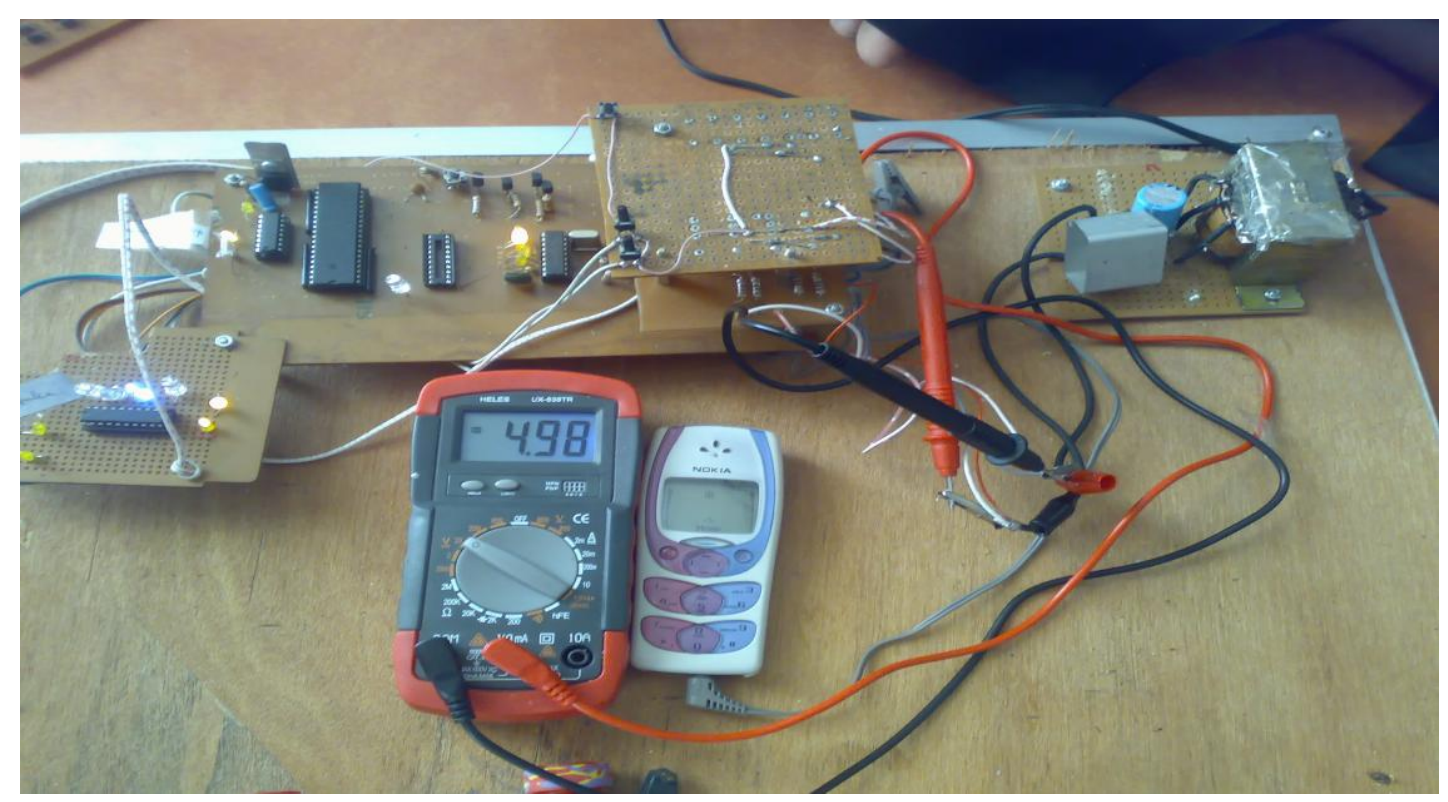

Gambar 4. Tampilan pengujian menggunakan volt meter

Analisa :

Dari hasil pengujian diperoleh tegangan output yang dihasilkan oleh IC LM7805 yaitu sebesar 4.98 volt dan memiliki error sebesar 0.02 Volt, akan tetapi mengacu pada data sheet bahwa secara teori besarnya tegangan output mencapai 5 volt. Dalam data sheet di sebutkan juga batas minimum 4.75 Volt dan maximum tegangan output 5.25 Volt yang dihasilkan. Hal ini disebabkan dari adanya faktor naik turunya tegangan PLN sehingga mempengaruhi tegangan input untuk IC 7805. Dari hasil pengukuran 
diperoleh tegangan output sebesar 4.98 Volt artinya tegangan output yang dihasilkan sudah bisa dikatakan mendekati tegangan normal.

\subsection{Pengujian IC MT8870D}

Pengujian ini untuk mengetahui IC MT8870 dapat menerima nada DTMF dari handphone pengendali dan mengirim dekoder DTMF ke rangkaian mikrokontroler.
Peralatan yang diperlukan dalam pengujian ini adalah :

1. Rangkaian led yang terhubung pada Q1,Q2,Q3,Q4

2. DC power supply +5 volt

3. Handphone nokia 2300

4. Handsfree

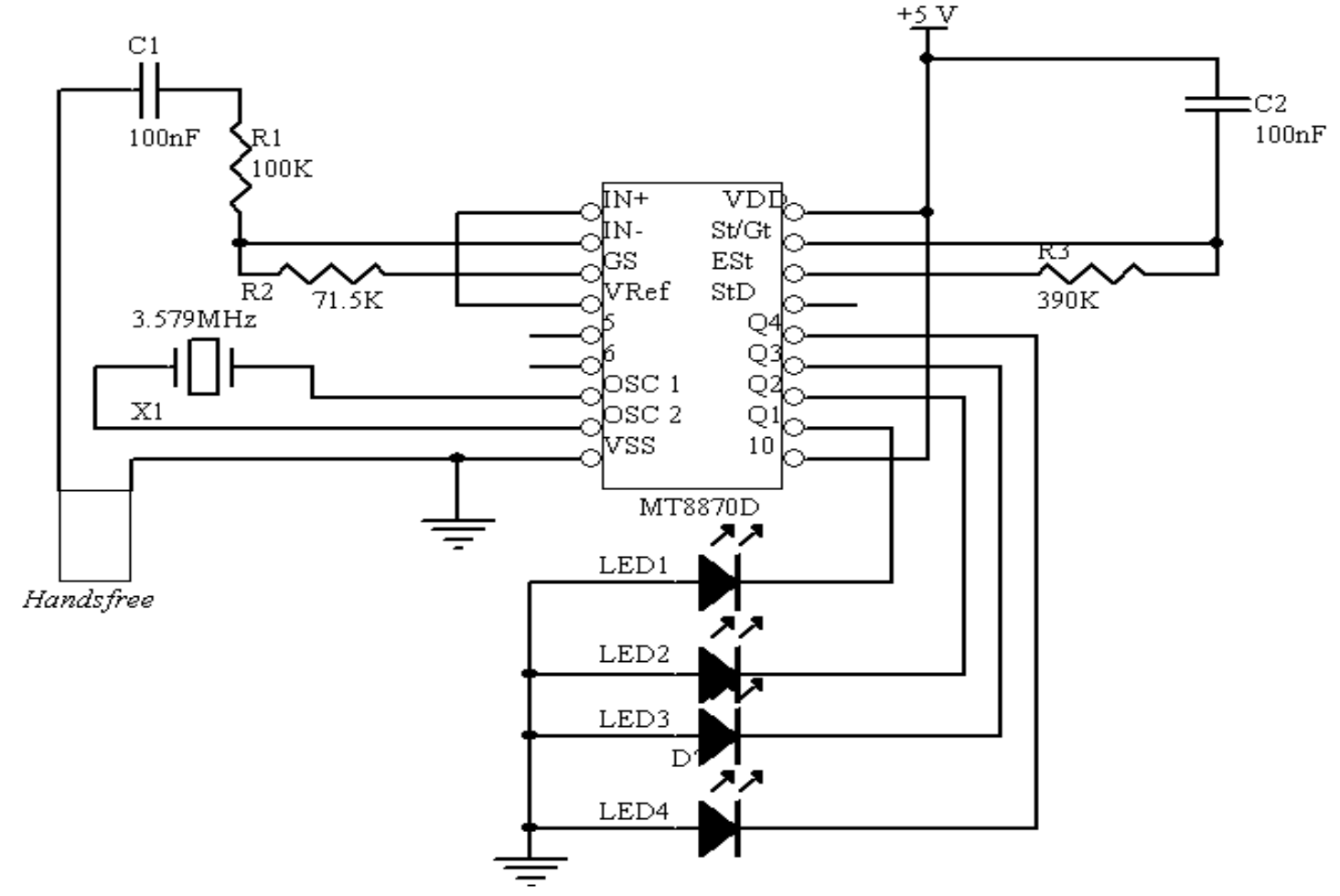

Gambar 5 Rangkaian pengujian IC MT8870

Setelah merangkai seperti gambar 5 maka handphone pengendali menghubungi

handphone receiver, menunggu auto answer

handphone receiver aktif, kemudian handphone pengendali menekan keypad 1 sampai 0 . Di peroleh hasil pengujian sebagai berikut:
Tabel 2. Hasil pengujian IC MT8870

\begin{tabular}{|c|c|c|c|c|}
\hline Keypad & LED4 & LED3 & LED2 & LED1 \\
\hline 1 & 0 & 0 & 0 & 1 \\
\hline 2 & 0 & 0 & 1 & 0 \\
\hline 3 & 0 & 0 & 1 & 1 \\
\hline 4 & 0 & 1 & 0 & 0 \\
\hline 5 & 0 & 1 & 0 & 1 \\
\hline 6 & 0 & 1 & 1 & 0 \\
\hline 7 & 0 & 1 & 1 & 1 \\
\hline 8 & 1 & 0 & 0 & 0 \\
\hline 9 & 1 & 0 & 0 & 1 \\
\hline 0 & 1 & 0 & 1 & 0 \\
\hline$*$ & 1 & 0 & 1 & 1 \\
\hline$\#$ & 1 & 1 & 0 & 0 \\
\hline
\end{tabular}


Keterangan :

$1=$ LED menyala

$0=$ LED mati

Analisa hasil pengujian :

Dari hasil pengujian dapat dilihat pada table 4.2 ternyata ketika angka satu ' 1 ' pada handphone pengirim di tekan maka dari sisi handphone penerima memberikan sinyal ke input IC DTMF, kemudian pada IC DTMF terjadi konversi dari pasangan frekuensi $697 \mathrm{~Hz}$ dan $1209 \mathrm{~Hz}$ menjadi kode biner 0001 dimana dalam kode biner ini dari hasil pengujian bisa dibuktikan dengan nyalanya led 1 , dimana kode biner ini digunakan sebagai input pada IC 74LS244, yang nantinya akan digunakan untuk pemicu kerjanya IC AT89S51. Tombol angka satu ini digunakan untuk membuka pintu gerbang. Sedangkan untuk menutup pintu gerbang, handphone pengirim cukup menekan tombol angka ' 8 ', dimana angka 8 ini termasuk gabungan frekuensi $852 \mathrm{~Hz}$ dan $1336 \mathrm{~Hz}$, kemudian setelah sinyal ini terdeteksi oleh IC 8870D maka frekuensi $852 \mathrm{~Hz}$ dan $1336 \mathrm{~Hz}$ akan dirubah ke bentuk kode biner yaitu menjadi biner 1000 dan dari hasil pengujian dibuktikan dengan led 4 menyala.

\subsection{Pengujian IC 74LS244}

Penguat IC 74LS244 digunakan sebagai penguat dari output IC DTMF yang akan menjadi suatu input dari mikrokontroler AT89S51. Berdasarkan pengukuran tegangan Outpu Q1, Q2, Q3, Q4 dari IC DTMF sebelum di hubungkan dengan IC Buffer 74LS244 sebesar 1.98 volt atau memiliki nilai logic ' 1 ' atau high. Setelah disambungkan dengan IC 74LS244 tegangannya menjadi 2.97 volt. Hal ini berarti IC 74LS244 dapat bekerja dengan baik. Berikut ini adalah hasil pengujiannya :

Tabel 3. Hasil pengujian IC 74LS244

\begin{tabular}{|c|c|c|c|c|c|c|c|}
\multicolumn{3}{|c|}{$\begin{array}{c}\text { Output IC DTMF 8870D } \\
\text { (Volt) }\end{array}$} & \multicolumn{5}{c|}{ Output IC 74LS244 } \\
(Volt) \\
\hline Q1 & Q2 & Q3 & Q4 & Y4 & Y3 & Y2 & Y1 \\
\hline 1.98 & 0 & 0 & 1.98 & 2.93 & 0 & 0 & 2.93 \\
\hline
\end{tabular}

Tabel 4. Hasil pengujian IC 74LS244 menggunakan volt meter

\begin{tabular}{|c|c|c|c|c|c|c|c|}
\hline \multicolumn{3}{|c|}{ Output IC DTMF 8870D } & \multicolumn{4}{|c|}{ Output IC 74LS244 } \\
\hline Q1 & $\mathrm{Q} 2$ & $\mathrm{Q} 3$ & $\mathrm{Q} 4$ & $\mathrm{Y} 4$ & $\mathrm{Y} 3$ & $\mathrm{Y} 2$ & $\mathrm{Y} 1$ \\
\hline 1 & 0 & 0 & 0 & 0 & 0 & 0 & 1 \\
\hline 0 & 0 & 0 & 1 & 1 & 0 & 0 & 0 \\
\hline
\end{tabular}

Analisa :

Dari hasil pengukuran didapatkan hasil seperti pada table 4. Dari hasil tersebut dapat kita analisa bahwa berdasarkan pada data sheet logic ' 1 ' untuk input high port P1, P2, P3 pada IC mikrokontroler AT89S51 memerlukan tegangan logic high minimal sebesar 2 volt, karena dari hasil pengukuran tegangan logic high output dari IC 8870D kurang memenuhi standart maka ditambahkan IC 74LS244 untuk menguatkan tegangan logic ' 1 ' atau high supaya mikrokontroler bekerja dengan baik.

\subsection{Pengujian Rangkaian Kartu}

Pengujian dilakukan dengan cara mengukur tegangan output infra red, yaitu pada port 3.6 terhadap ground untuk sensor infra red yang pertama, dan port 3.7 terhadap ground untuk sensor infra red yang kedua. Apabila Infra Red terkena cahaya maka tegangan outputnya harus 'high' atau $5 \mathrm{~V}$ dan apabila Infra Red tidak terkena cahaya maka tegangan outputnya harus 'low' atau $0 \mathrm{~V}$. Hasil pengukuran tegangan output infra red di perlihatkan pada Tabel 5.

Driver kartu digunakan sebagai

sklar, dimana rangkaian ini menggunakan transistor BC547. Pada blok driver kartu menggunakan resistor colector yang memiliki nilai hambatan $100 \Omega$.

Untuk mengetahui kebenaran teori bahwa $\mathrm{Vcc}=5$ volt maka dilakukan pembuktian menggunakan rumus, yaitu :

$$
\begin{array}{ll}
\text { Diketahui } & : \mathrm{Rc}=100 \Omega \\
& \mathrm{Ic}=2 \mathrm{~mA}(\text { data sheet }) \\
\text { Ditanya } & : \text { Vce } \\
\text { Jawab } & : V_{C E}=V_{C C}-I_{C}\left(R_{C}+R_{E}\right) \\
& V_{C E}=5 v-2 m A(100+0) \\
& V_{C E}=5 v-0.02 v
\end{array}
$$




$$
V_{C E}=4.98 \text { Volt }
$$

saat melakukan pengukuran menggunakan alat ukur nilai Vce adalah 4.98 Volt.

Resistor $10 \mathrm{~K} \Omega$ terhubung dengan kaki colector pada transistor BC547. Berdasarkan teori yang didapatkan dari data sheet bahwa tegangan Vce adalah 5 volt sedangkan pada

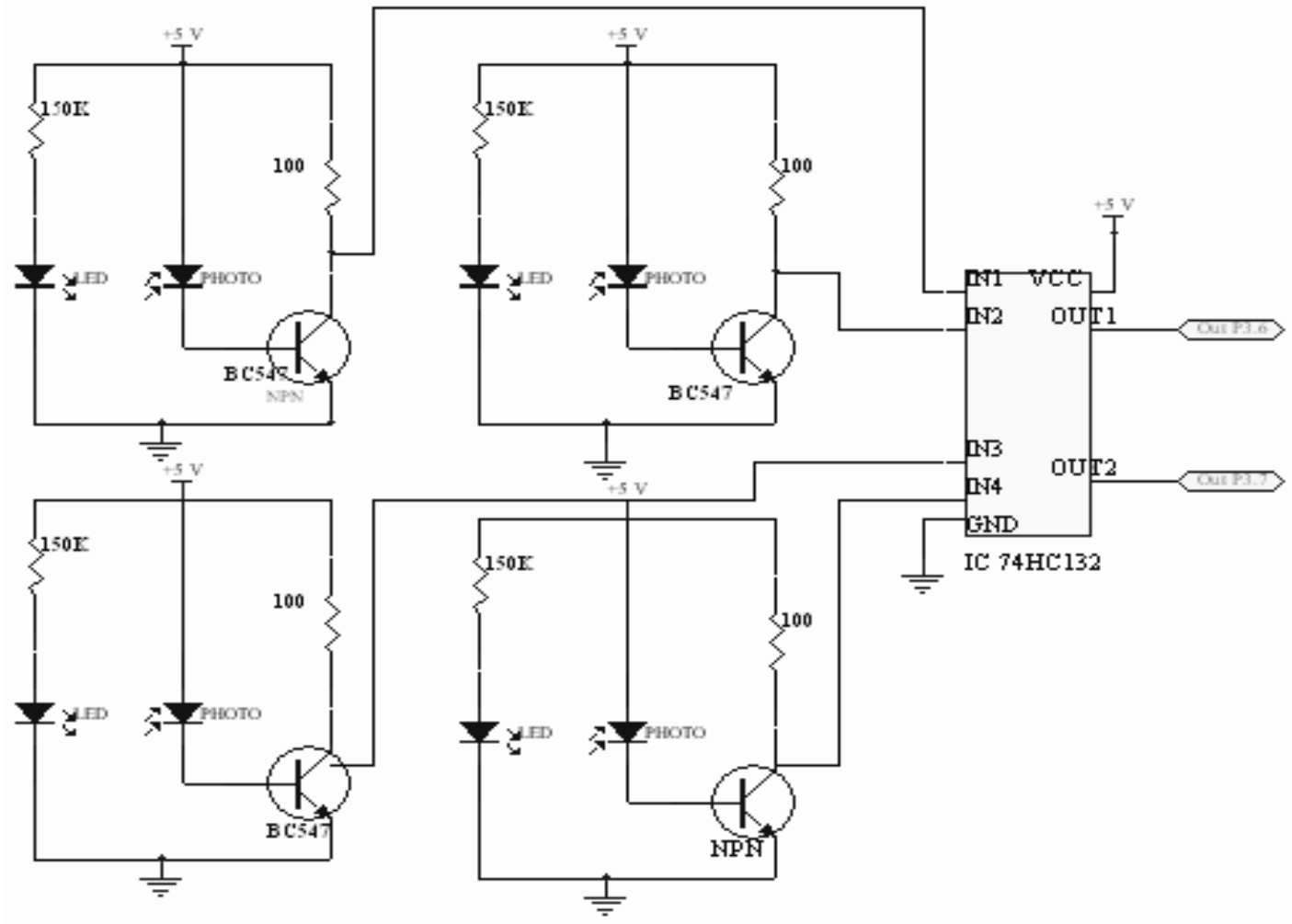

Gambar 6. Rangkaian pengujian sensor kartu

Nilai Vce yang digunakan sebagai input untuk IC 74HC132 yaitu sebesar 4.98 volt (dari pengukuran) mengalami penurunan tegangan yaitu sebesar 1.98 volt, tegangan 1.98 volt inilah yang akan memicu kinerja dari mikrokontroler. Pada IC 74HC132 menampung sinyal tegangan dari empat sensor yang digunakan, dimana kombinasi sensor yang digunakan ialah menyilang. Untuk membuka pintu kartu cukup dimasukan ke driver kartu kemudian untuk membukanya cukup dengan mencabut kartu dari driver kartu.

Tabel 5. hasil pengujian sensor infra red (IR)

\begin{tabular}{|c|c|c|c|c|}
\hline \multirow[t]{2}{*}{ Keadaan Sensor } & \multicolumn{3}{|c|}{$\begin{array}{c}\text { Tegangan pada output IC } \\
74 \mathrm{HC} 132 \text { (Volt) }\end{array}$} & \multirow{2}{*}{$\begin{array}{c}\text { Keadaan Pada } \\
\text { Sensor Infra } \\
\text { Merah }\end{array}$} \\
\hline & Teori & Pengukuran & Error & \\
\hline $\begin{array}{l}\text { Terhalang kartu, } \\
\text { sensor } 2 \text { dan } 4\end{array}$ & 0 Volt & 0.09 volt & t0.09 volt & $\begin{array}{c}\text { Tidak Aktif (pintu } \\
\text { terbuka) }\end{array}$ \\
\hline $\begin{array}{c}\text { Tidak Terhalang } \\
\text { kartu, sensor } 2 \text { dan } 4\end{array}$ & 5 Volt & 1.98 volt & $\# 3.02$ volt & $\begin{array}{l}\text { Aktif(pintu } \\
\text { tertutup) }\end{array}$ \\
\hline
\end{tabular}

Anali 
Dari hasil pengukuran tersebut sudah sesuai dengan yang di harapkan, artinya rangkaian sensor sudah dapat bekerja dengan baik karena sudah mencapai nilai logic high untuk memicu mikrokontroler pada port P3.6 untuk membuka pintu gerbang. Dari tabel 5 terdapat selisih nilai tegangan, saat sensor terhalang kartu error sebesar 0.09 hal ini tidak mempengaruhi sistem kerja mikrokontroler karena logic low bernilai tegangan minimal 0 volt sampai dengan 0.45 volt untuk input low pada mikrokontroler. Saat sensor tidak terhalang oleh kartu error 3.02 volt, akan tetapi hal ini tidak mengakibatkan unjuk kerja mikrokontroler terganggu karena input high yang dibutuhkan oleh mikrokontroler 2 volt sampai 5 volt dan memiliki toleransi tegangan sebesar $10 \%$. Standar input pada IC mikrokontroler AT89S51 ada pada datasheet mikrokontroler.

\section{KESIMPULAN DAN SARAN}

\subsection{KESIMPULAN}

1. Untuk membuat sistem kendali pintu dengan menggunakan mikrokontroler AT89S51 perlu pemrograman dengan menggunakan bahasa assembly dan kondisikan pemakaian port $\mathrm{P} 0, \mathrm{P} 1$, P2, dan P3 sebagai input dan output mikrokontroler. Pada sitem ini menggunakan port $\mathrm{P} 0.0, \mathrm{P} 0.1, \mathrm{P} 02$, P0.3 digunakan sebagai input intruksi untuk mikrokontroler dari IC MT8870D, port P3.6 dan P3.7 digunakan untuk input mikrokontroler dari sistem kartu teridentifikasi sehingga ketika mikrokontroler mendapatkan input intruksi maka kondisi pintu akan terbuka atau tertutup sesuai dengan intruksi yang di input.

2. IC DTMF digunakan untuk mengkonversi penekanan tombol 1 dari pasangan frekuensi $697 \mathrm{~Hz}$ dan $1209 \mathrm{~Hz}$ menjadi kode biner 0001 . Kode biner ini digunakan sebagai input IC AT89S51 pada pin P0.0,
P0.1, P0.2, P0.3,. tombol angka satu ini digunakan untuk membuka pintu gerbang. Sedangkan untuk menutup pintu gerbang, handphone pengirim cukup menekan tombol angka ' 8 ', angka 8 ini termasuk gabungan frekuensi $852 \mathrm{~Hz}$ dan $1336 \mathrm{~Hz}$, kemudian setelah sinyal ini terdeteksi oleh IC 8870D maka frekuensi $852 \mathrm{~Hz}$ dan $1336 \mathrm{~Hz}$ akan dirubah ke bentuk kode biner yaitu menjadi biner 1000

3. Driver kartu untuk kombinasi sensor dibutuhkan IC 74HC132 supaya dari dua output sensor dijadikan satu input untuk mikrokontroler di port P3.6. logic '1' yang dibutuhkan untuk memicu kerja mikrokontroler yaitu $\min 1.98$ volt.

4. Setelah dilakukan pengujian, alat ini hanya mengeksekusi perintah dari sistem kendali mana yang digunakan apakah kartu atau handphone. Jika menggunakan kartu untuk membuka pintu maka untuk menutup pintunya harus menggunakan kartu juga begitu juga sebaliknya ketika menggunakan handphone.

\subsection{SARAN}

1. Menambah relay pada port P2.4, P2.5, P2.6, P2.7, P3.1, P3.2, P3.3, P3.4, P3.5 karena masih belum terpakai sehingga dapat digunakan untuk alat kendali rumah tangga misalnya menghidupkan lampu, pompa air, atau TV.

2. Menambah atau mengubah dalam bagian software dan hardware sedemikian rupa sehingga alat ini akan mengirimkan SMS (Short Message Service) dengan memanfaatkan fasilitas handphone untuk sms cepat.

3. Menambah atau mengubah bagian software dan hardware sedemikian rupa sehingga alat ini akan memberikan informasi berupa panggilan, dimana konfigurasi di hanphone di setting auto dial. 


\section{DAFTAR PUSTAKA}

[1]. Agfianto Eko Putra, "Belajar Mikrokontroler AT89C51/52/55 Teori dan Aplikasi” Gava Media, Yogyakarta 2006

[2]. Budiharto widodo, dkk, "12 Proyeksi mikrokontroler untuk pemula"

Gramedia, Jakarta 2007

[3]. Data Sheet Mikrokontroller AT89S51 http://www.com/apnotes/Others_v12. $\mathrm{html}=$ aplication note national_ (diakses pada tanggal 26 maret 2009 pukul 23.40)

[4]. Data Sheet IC MT8870D http://www.alldatasheet.com/datashee t-pdf / pdf/ 77074 / MITEL / MT8870D.html (diakses pada tanggal 19 mei 2009 pukul 13.01)

[5]. Data Sheet IC 74LS244 http://www.alldatasheet.com/datashee t-pdf/pdf/28030/TI/74LS244.html (diakses pada tanggal 19 mei 2009 pukul 13.20)

[6]. Data Sheet IC L293D http://pdf1.alldatasheet.com/datasheet -pdf/view/22432/

STMICROELECTRONICS

L293D.html (diakses pada tanggal 19 mei 2009 pukul 13.22)

[7]. Data Sheet Phototransistor http://www.fairchildsemi.com/ds/QS\% 2FQSC113.pdf. (diakses pada tanggal 19 mei 2009 pukul 14.20)

[8]. Data Sheet Inframerah http://www.moxtek.com/PDF/Optical \%20PDF/Infrared\%20Data\%20Sheet.p df (diakses pada tanggal 19 mei 2009 pukul 14.50)

[9]. Data Sheet Motor DC http://konversi.wordpress.com/2008/0 9/01/motor-arus-searah-dcbagaimana - bekerjanyal (diakses pada tanggal 20 mei 2009 pukul 15.02)

[10]. Data Sheet Buzzer

http://www.milram.com/pdf/literature/DS-TA20012002.pdf, (diakses pada tanggal 20 mei 2009 pukul 15.22)

[11]. Susanto, Irwan, 2004. "Pedoman Penulisan Tugas Akhir Akademi Teknik Telekomunikasi Sandhy Putra Purwokerto".

[12]. Suhata, "Aplikasi Mikrokontroler Sebagai Pengendali Peralatan Elektronik Via Line Telepon" Elex Media Komputindo, Jakarta 2005

[13]. Paulus Andi Nalwan, "Panduan Praktis Teknik Antar Muka dan Pemrograman Mikrokontroler At89C51" Elex Media Komputindo, Jakarta 2005

[14]. Scott MecKenzie, "THE 8051 MICROCONTROLLER" "third edition.upper Saddle River, New Jersey Columbus 